\title{
USE OF THE MUSCLE DIGESTION METHOD AND INDIRECT IMMUNOFLUORESCENCE REACTION IN THE DIAGNOSIS OF SARCOCYSTOSIS IN SHEEP
}

\author{
Vlasta SVOBODOVA and M. NEVOLE
}

\author{
Department of Pathological Morphology and Parasitology, University of Veterinary Science, \\ 61242 Brno
}

Received fune 8, 1989

\begin{abstract}
Svobodová Vlasta, M. Nevole: Use of the Muscle Digestion Method and Indirect Immunofluorescence Reaction in the Diagnosis of Sarcocystosis in Sheep. Acta vet. Brno, 59, 1990: 157-170.

A total of 1014 sheep (522 ewes, 150 rams and 342 lambs) from the catchment-areas of the abattoirs of Tišnov, Klatovy, Strakonice and Nymburk were subjected to direct and indirect examination for sarcocystosis between October 1985 and June 1988.

Direct examination with the muscle digestion method revealed muscle cysts in $75.10 \%, 64.67 \%$ and $35.67 \%$ of the ewes, rams and lambs, respectively. The ratio of macrocysts to microcysts was $22: 608$. Macrocysts were found only in adult sheep (in $3.27 \%$ of the ewes and rams) and, except one case where they were detected in both the the oesophagus and the diaphragm, were located exclusively in the oesophagus. Microcysts were located predominantly in the diaphragm and the intensity of their occurrence increased significantly $(P<0.005)$ with the age of the animals.

Serological examination of the blood using the indirect immunofluorescence reaction (IFR) detected specific antibodies in $88.70 \%, 91.22 \%$ and $94.44 \%$ of the ewes, rams and lambs, respectively. In adult sheep the results of the two methods of examination coincided in $71.87 \%$ of the animals, whereas a high dynamic discrepancy was found in $61.69 \%$ of the lambs. A highly significant $(P<0.005)$ correlation was found between the direct demonstration of muscle cysts and the specific antibody titre of 40 and higher as recorded for the IFR.
\end{abstract}

Microcysts, macrocysts, antibody, age-dependence

Sarcocystosis is a parasitic disease affecting sheep in the intermediate-host phase of the life cycle of the causative agent. The genus Sarcocystis is classified within the group of obligately heteroxenic coccidia. Two months to 1 year after ingestion of the sporocysts muscle cysts develop (Dubey 1977) that are infective for the definitive host - canines and felids. The species found most frequently in our country are those producing microcysts - Sarcocystis arieticanis and Sarcocystis ovicanis where the definitive host is the dog. Macrocysts are characteristics of Sarcocystis gigantea where the definitive host is the cat. It is a well-established fact that pathogenic species of canine sarcocysts can produce clinical disease (inappetence, anaemia, fever, abortions) mainly in lambs and pregnant ewes. Sarcocyst species having the cat as their definitive host are regarded as non-pathogenic (Dubey 1986). Economic loss is due to gross lesions of the musculature.

From the epizootiological point of view ovine sarcocystosis can be regarded as a wide-spread disease. From the data reported abroad it appears that the proportions of positive animals ranged from $6.7 \%$ to $100 \%$, depending mainly on the method of examination (Afshar et al. 1974; Boch et al. 1978; Diéz-Baňos 1978; Britt and Baker 1983; O'Donoghue and Ford 1986; Adamczyk and Chmielowski 1987; Arnaudov and Belchev 1987; Pomroy and Charleston 1987, a. o.). In our country Andraško (1982) found macrocysts in $35 \%$ of sheep in Slovakia. 
More detailed data were reported by Gut (1982) using the muscle digestion method; he found macrocysts in $92 \%$ of sheep. Černá and Merhautová (1981) diagnosed sarcocystosis in $82 \%$ of sheep slaughtered at Prague abattoir. Donát (1986) examining the oesophagi of 638 sheep reported positive findings in 102 of them: macrocysts in $5(4.0 \%)$ and microcysts in $97(95.1 \%)$ animals. Svobodová and Nevole (1985) diagnosed sarcocystosis in $64.9 \%$ of pooled muscle samples from ewes, rams and lambs. The highest specific antibody titres ranging from 640 to 10240 were found by Nevole et al. (1984) in 16 broilers and 26 ewes. From the afore-mentioned evidence it appears that the extent of sarcocystosis in our sheep flocks is considerable.

Preventive measures are based on the knowledge of the life cycle of the parasite. Under natural conditions the intermediate host becomes infected by ingestion of sporocyst-contaminated food or water. The resistance of sporocysts in the environment is considerable: under conditions of sufficient humidity they can survive for more than one year (Bergler et al. 1980).

The present study was designed to assess the possibility of diagnosing sarcocystosis in sheep under our conditions with reference to its incidence in animals of various ages.

\section{Materials and Methods}

Direct and indirect examination of sheep focussed on the incidence and diagnosis of sarcocystosis was carried out from October 1985 to June 1988. A total of 1014 sheep (mainly Merino and its crosses) of various ages were examined. A survey of the animals is presented in Table 1 . Group 1 included 522 ewes, Group 2 included rams and wethers (150 animals) and Group 3 consisted of lambs - broilers and young animals between 6 and 12 months of age ( 342 animals). The adult sheep were between 3 and 8 years of age. The animals originated from the catchment-areas of the abattoirs of Tišnov, Nymburk, Klatovy and Strakonice.

Samples of oesophageal and diaphragm muscle and a blood sample were taken from each animal at slaughter in the abattoir. The muscle samples were examined with direct methods. Where visual inspection of the samples revealed macrocysts, the entire oesophageal and diaphragm muscles were carefully examined directly at the abattoir. For microscopic examination, samples of $15 \mathrm{~g}$ each were taken from the oesophageal and diaphragm muscles and cut with scissors to pieces of the size of an oat grain. Afterwards they were processed with the digestion and homogenization method as described by Nevole and Lukešová (1981). The resultant sediment was examined for the presence of cysts and their fragments under a light microscope at $\times 80$ to 200. The sarcocysts were not differentiated there to species but were only divided into macrocysts and microcysts. The intensity of the incidence of the cysts was graded as follows: $+(1$ to 2 cysts $),++$ ( 3 to 5 cysts) and $+++(6$ and more cysts in the whole sediment). Species differentiation of the sarcocysts was carried out on a limited number of the samples under a Tesla scanning electron microscope at the Veterinary Research Institute, Brno.

Blood samples collected from the sheep were allowed to clot and then centrifuged at $1500 \mathrm{rpm}$. The sera were stored at $-18^{\circ} \mathrm{C}$ until tested. The serological diagnostic method was the indirect immunofluorescence reaction (IFR) using corpuscular antigen obtained from $S$. gigantea macrocysts and rabbit anti-sheep gamma globulin conjugate RES/FITC labelled with fluoresceinisothiocyanate. The procedure was described in detail by Svobodova (1989). The results of the serological reaction were checked by including a system of control with negative serum (precolo-

Table 1

Survey of the sheep examined

\begin{tabular}{|c|c|c|c|c|c|c|}
\hline \multirow{2}{*}{$\begin{array}{l}\text { Sheep } \\
\text { cathegory }\end{array}$} & \multicolumn{2}{|c|}{$\begin{array}{l}\text { Sheep from state } \\
\text { farms }\end{array}$} & \multicolumn{2}{|c|}{$\begin{array}{l}\text { Sheep from private } \\
\text { farms }\end{array}$} & \multicolumn{2}{|c|}{ Total } \\
\hline & No. & $\%$ & No. & $\%$ & No. & $\%$ \\
\hline $\begin{array}{l}\text { Ewes } \\
\text { Rams } \\
\text { Lambs }\end{array}$ & $\begin{array}{r}160 \\
43 \\
152\end{array}$ & $\begin{array}{r}15.78 \\
4.24 \\
14.99\end{array}$ & $\begin{array}{l}362 \\
107 \\
190\end{array}$ & $\begin{array}{l}35.70 \\
10.55 \\
18.74\end{array}$ & $\begin{array}{l}522 \\
150 \\
342\end{array}$ & $\begin{array}{l}51.48 \\
14.79 \\
33.74\end{array}$ \\
\hline Total & 355 & 35.01 & 659 & 64.99 & 1014 & 100.00 \\
\hline
\end{tabular}


Table 2

Results of direct examination of the oesophagus and diaphragm muscles in ewes, rams and lambs

\begin{tabular}{|c|c|c|c|c|c|c|c|c|c|c|c|}
\hline \multirow{3}{*}{$\begin{array}{l}\text { Sheep } \\
\text { category }\end{array}$} & \multirow{3}{*}{$\begin{array}{c}\text { Total } \\
\text { No. of } \\
\text { ani- } \\
\text { mals }\end{array}$} & \multirow{2}{*}{\multicolumn{2}{|c|}{$\begin{array}{l}\text { Negative } \\
\text { animals }\end{array}$}} & \multicolumn{8}{|c|}{ Positive animals } \\
\hline & & & & \multicolumn{2}{|c|}{$\begin{array}{c}\text { Cysts only } \\
\text { in } \\
\text { oesophagus }\end{array}$} & \multicolumn{2}{|c|}{$\begin{array}{c}\text { Cysts only } \\
\text { in } \\
\text { diaphragm }\end{array}$} & \multicolumn{2}{|c|}{$\begin{array}{c}\text { Cysts in both } \\
\text { tissues }\end{array}$} & \multicolumn{2}{|c|}{ Total } \\
\hline & & No. & $\%$ & No. & $\%$ & No. & $\%$ & No. & $\%$ & No. & $\%$ \\
\hline $\begin{array}{l}\text { Ewes } \\
\text { Rams } \\
\text { Lambs }\end{array}$ & $\begin{array}{l}522 \\
150 \\
342\end{array}$ & $\begin{array}{r}130 \\
53 \\
220\end{array}$ & $\begin{array}{l}24.90 \\
35.33 \\
64.33\end{array}$ & $\begin{array}{l}72 \\
18 \\
18\end{array}$ & $\begin{array}{r}13.79 \\
12.00 \\
5.26\end{array}$ & $\begin{array}{r}146 \\
45 \\
72\end{array}$ & $\begin{array}{l}27.97 \\
30.00 \\
21.05\end{array}$ & $\begin{array}{r}174 \\
34 \\
32\end{array}$ & \begin{tabular}{|r|}
33.34 \\
22.67 \\
9.36
\end{tabular} & $\begin{array}{r}392 \\
97 \\
122\end{array}$ & $\begin{array}{l}75.10 \\
64.67 \\
35.67\end{array}$ \\
\hline Total & 1014 & 403 & 39.74 & 108 & 10.65 & 263 & 25.94 & 240 & 23.67 & 611 & 60.26 \\
\hline
\end{tabular}

stral lamb serum), without serum and with positive serum obtained by triplictae examination of highly positive animals. The preparations were evaluated in a Jenalunar 30-60050 immunofluorescence microscope by immersion at 630 (i. e. $100 \times 6.3$ ).

The significance of the results was assessed by the chi-squared test $(2 \times 2$ table and $\mathrm{k} \times \mathrm{m}$ table) according to Reisenauer (1970) in a TNS SC computer (Slušovice).

\section{Results}

The results of direct demonstration of cysts in the oesophagus and diaphragm muscles of the sheep together with their location are presented separately for ewes, rams and lambs in Table 2. Sarcocystosis was demonstrated in a total of $611(60.26 \%)$ sheep. The highest proportion of positive findings was recorded in ewes and the lowest in lambs. Comparison of the incidence of the cysts in the oesophagus only with that recorded only in the diaphragm and concurrently in the two tissues shows that in lambs the cysts were located mainly in the diaphragm, whereas their incidence in the oesophagus and concurrently in the two tissues can be regarded as sporadic. In adult sheep cysts were found mainly only in the diaphragm or concurrently in the two organs. These relations proved to be highly significant $(P<0.005)$. Total evaluation of direct demonstration of the cysts in adult sheep (older than 1 year) and lambs (up to 1 year of age) is presented in Table 3; the increase of the cysts with age was highly significant $(P<0.005)$. The same became apparent upon comparison of the findings obtained in ewes, rams and lambs $(P<0.005)$.

A survey of the incidence of macrocysts and microcysts is shown in Table 4. It can be seen that findings of macrocysts were considerably fewer than those of microcysts ( 22 vs. 608). The location of macrocysts and the proportions of affected animals are shown in Table 5. Macrocysts (Fig. 1 and 2) were found only in adult sheep and the predilection site of their location was the oesophagus. Only in one instance macrocysts were found in both the diaphragm and the oesophagus. The proportions of ewes, rams and lambs showing sarcocysts in the oesophageal and diaphragm muscles are presented, together with the intensity of infection, in Table 6 summarizing 851 positive findigs in 611 sheep. The cysts were significantly $(P<0.05)$ more frequent in the diaphragm than in the oesophagus. It is obvious that this significantly higher proportion of cysts in the diaphragm was due 
Table 3

Age-dependence of the incidence of sarcocysts in sheep

\begin{tabular}{|l|c|c|c|c|c|c|c|c|}
\hline \multirow{2}{*}{ Age of sheep } & \multicolumn{2}{|c|}{ Positive sheep } & \multicolumn{2}{|c|}{ Negative sheep } & \multicolumn{2}{|c|}{ Total } & Statistical \\
\cline { 2 - 7 } & No. & $\%$ & No. & $\%$ & No. & $\%$ & significance \\
\hline Up to 1 year & 122 & 35.67 & 220 & 64.33 & 342 & 100.00 & P $<0.005$ \\
Over 1 year & 489 & 72.77 & 183 & 27.23 & 672 & 100.00 & \\
\hline Total & 611 & 60.26 & 403 & 39.74 & 1014 & 100.00 & - \\
\hline
\end{tabular}

Table 4

Survey of the incidence of macrocysts and microcysts

\begin{tabular}{|l|c|c|c|c|r|}
\hline \multicolumn{1}{|c|}{ Type of cyst } & \multicolumn{2}{|c|}{ Sheep } & Type of cyst & \multicolumn{2}{c|}{ Findings } \\
\cline { 2 - 6 } & No. & $\%$ & & No. & $\%$ \\
\hline $\begin{array}{l}\text { Only macrocysts } \\
\begin{array}{l}\text { Concurrent findings of } \\
\text { macrocysts and micro- } \\
\text { cysts } \\
\text { Only microcysts }\end{array}\end{array}$ & 3 & $0.49 \rightarrow$ & Macrocysts & 22 & 3.49 \\
\hline Total sheep & 589 & $96.40 \rightarrow$ & Microcysts & 608 & 96.51 \\
\hline
\end{tabular}

Table 5

Proportions of sheep showing macrocysts

\begin{tabular}{|l|c|c|c|c|r|r|}
\hline \multirow{2}{*}{ Sheep category } & \multirow{2}{*}{$\begin{array}{c}\text { Total No. } \\
\text { examined }\end{array}$} & $\begin{array}{c}|c| \\
\text { only in } \\
\text { oesophagus }\end{array}$ & $\begin{array}{c}\text { only in } \\
\text { diaphragm }\end{array}$ & $\begin{array}{c}\text { in both } \\
\text { tissues }\end{array}$ & No. & $\%$ \\
\hline Ewes & 522 & 17 & 0 & 1 & 18 & 3.45 \\
Rams & 150 & 4 & 0 & 0 & 4 & 2.67 \\
Lambs & 342 & 0 & 0 & 0 & 0 & 0.00 \\
\hline Total & 1014 & 21 & 0 & 1 & 22 & 2.17 \\
\hline
\end{tabular}

predominantly to the contribution of microcysts (Fig. 3 and 4). The intensity of infection in both the oesophagus and the diaphragm increased with age, amounting to ${ }^{++}$to ${ }^{+++}$. This increase was highly significant $(P<0.005)$ and was more pronounced in the diaphragm.

Each direct examination of the oesophagus and diaphragm muscles in 1014 sheep was supplemented by serological examination using the IFR technique. 


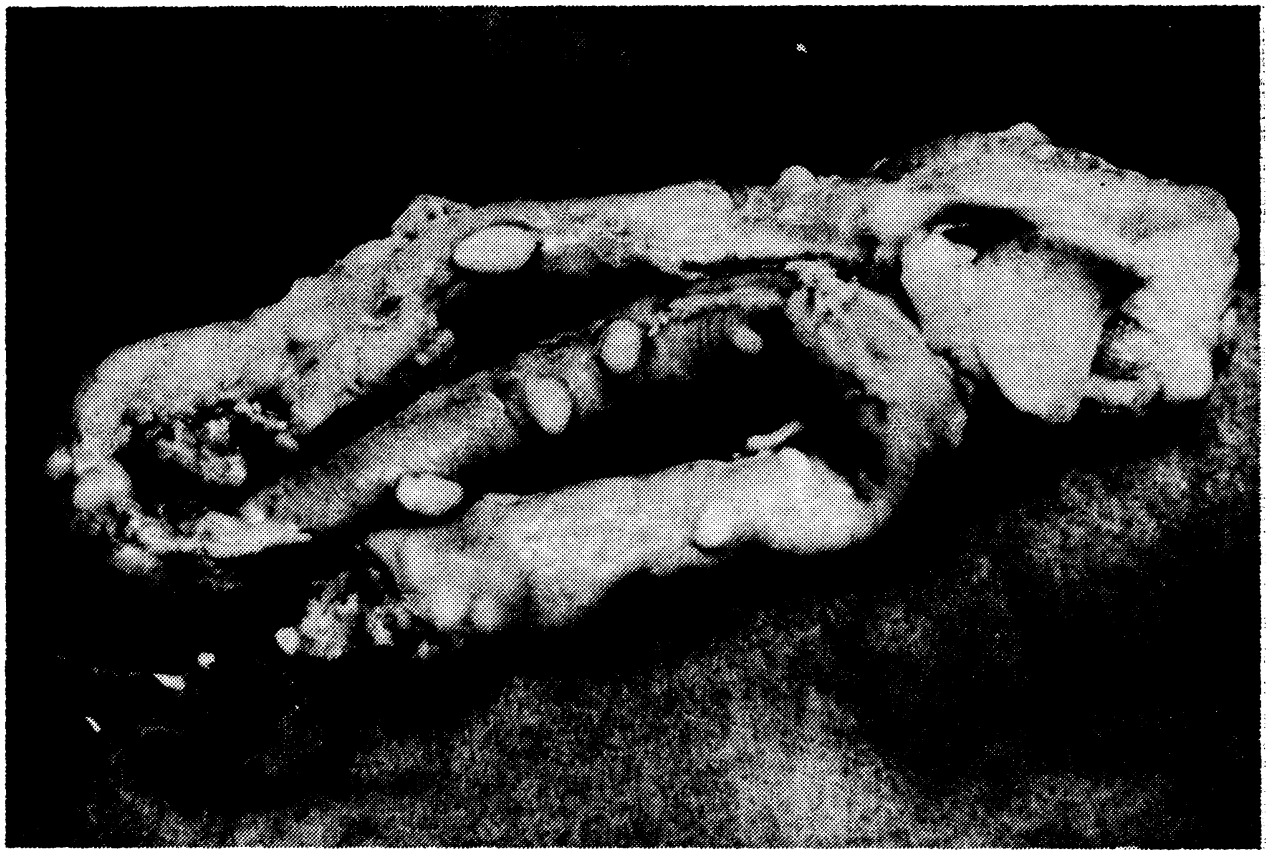

Fig. 1. Macrocysts in the oesophageal muscle

Fig. 2. Cauliflower-like structure of the primary wall of a $S$. gigantea macrocyst with released zoites (scanning electron microscope $\times 10000$ ).

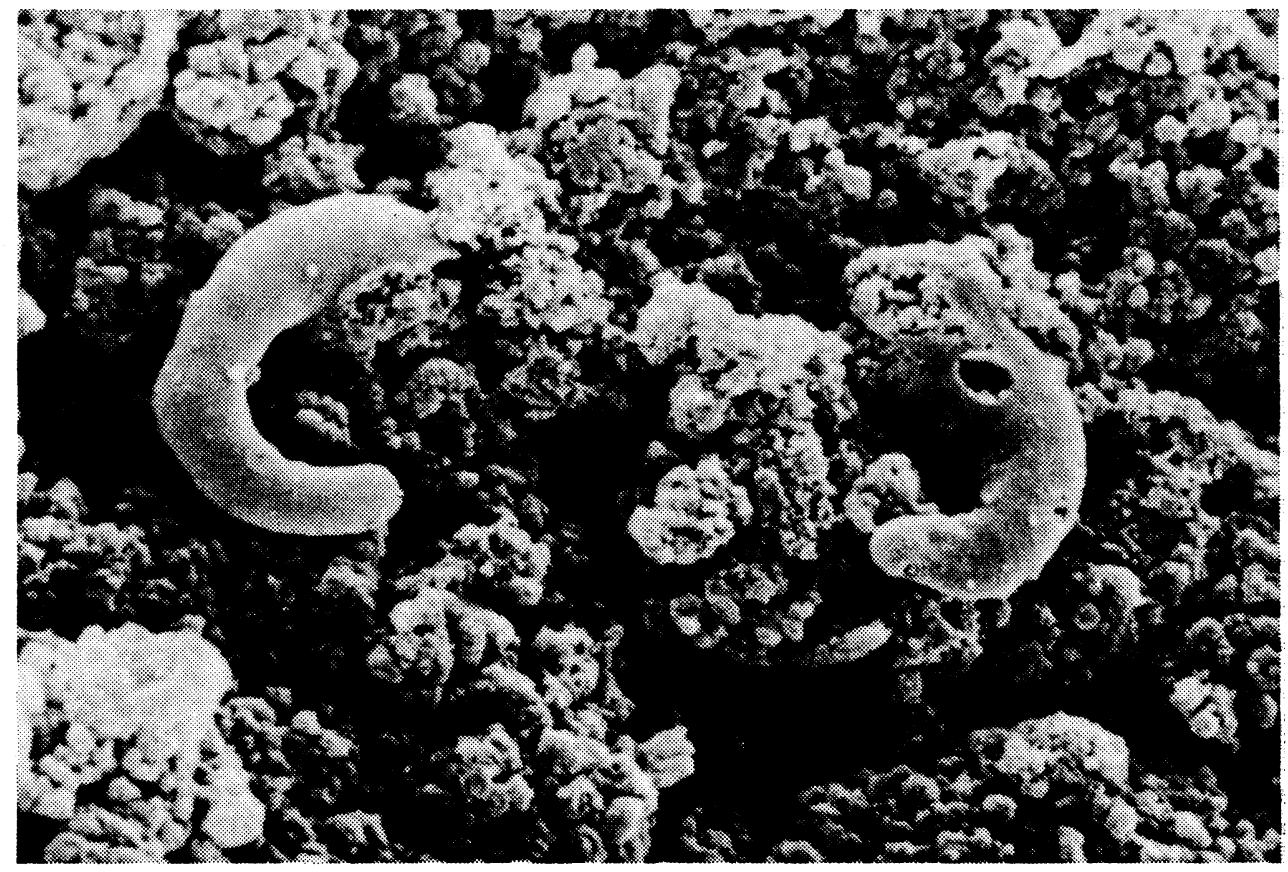




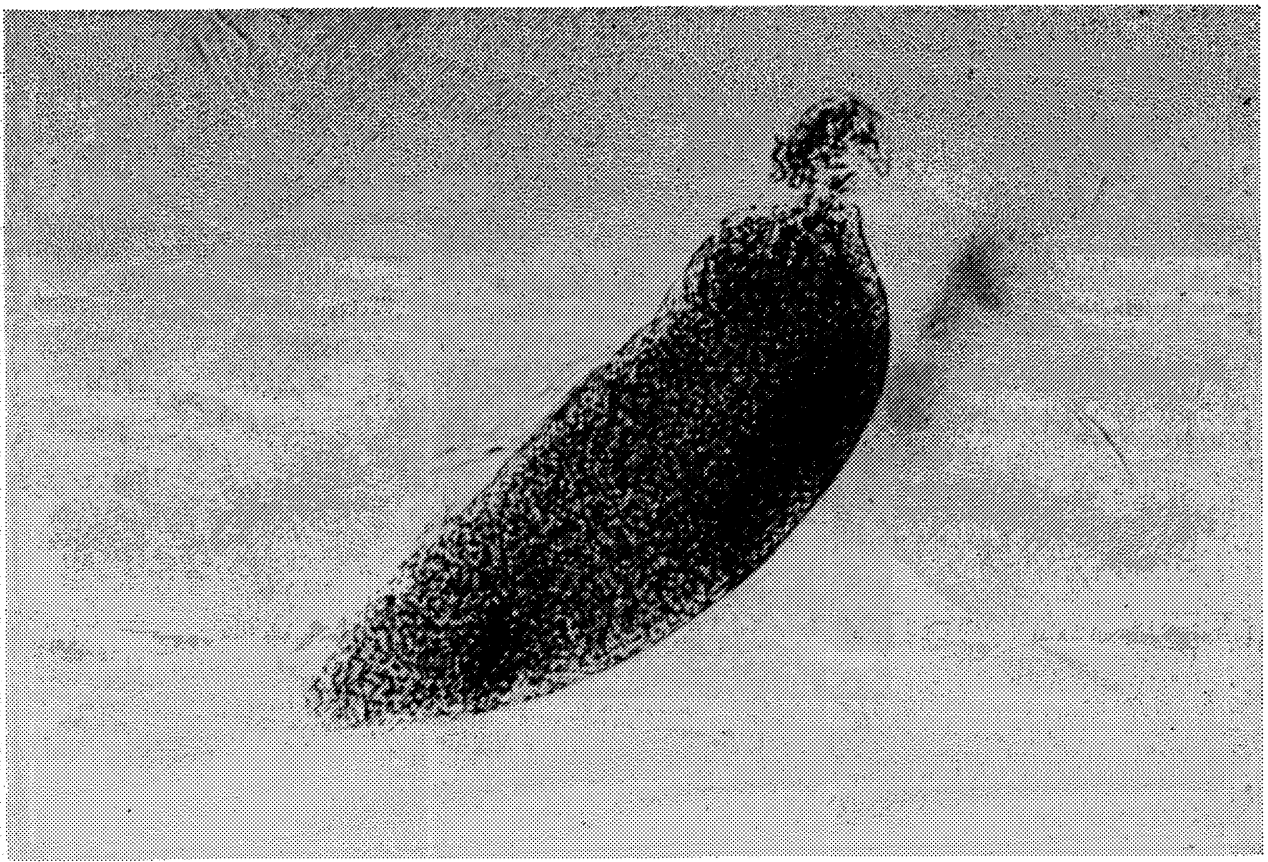

Fig. 3. A microcyst obtained by the muscle digestion method (light microscope $\times 100$ ).

Fig. 4. Surface of a $S$. ovicanis microcyst with finger-like projections (scanning electron microscope $\times 5000)$.

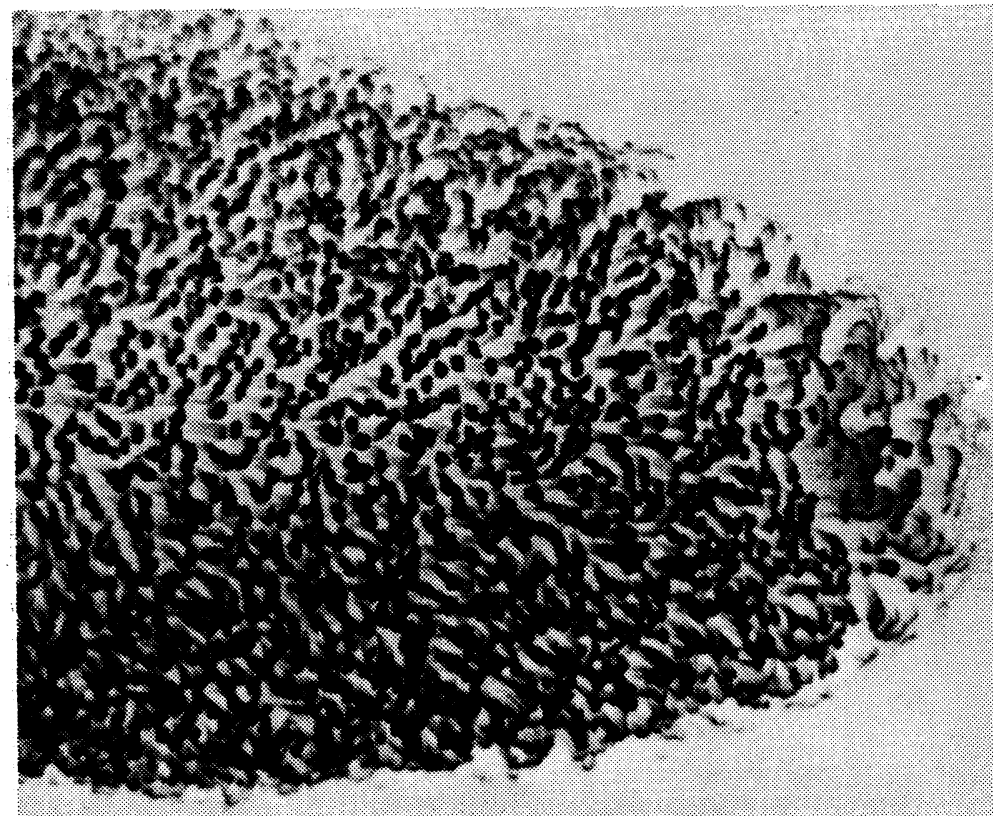


Table 6

Proportions of sarcocyst-infected ewes, rams and lambs and the intensity of their infection

\begin{tabular}{|c|c|c|c|c|c|c|}
\hline \multirow{3}{*}{$\begin{array}{l}\text { Intensity } \\
\text { of infection }\end{array}$} & \multicolumn{6}{|c|}{ Positive findings } \\
\hline & \multicolumn{2}{|c|}{ Ewes } & \multicolumn{2}{|c|}{ Rams } & \multicolumn{2}{|c|}{ Lambs } \\
\hline & No. & $\%$ & No. & $\%$ & No. & $\%$ \\
\hline $\begin{array}{l}\text { Oesophagus } \\
\text { Weak }(+) \\
\text { Medium }(++) \\
\text { Heavy }(+++)\end{array}$ & $\begin{array}{r}159 \\
49 \\
38\end{array}$ & $\begin{array}{r}28.09 \\
8.66 \\
6.71\end{array}$ & $\begin{array}{r}37 \\
9 \\
6\end{array}$ & $\begin{array}{r}28.04 \\
6.87 \\
4.58\end{array}$ & $\begin{array}{r}45 \\
4 \\
1\end{array}$ & $\begin{array}{r}29.22 \\
2.60 \\
0.65\end{array}$ \\
\hline Total oesophagus & 246 & 43.46 & 52 & 39.69 & 50 & 32.47 \\
\hline $\begin{array}{l}\text { Diaphragm } \\
\text { Weak }(+) \\
\text { Medium }(++) \\
\text { Heavy }(+++)\end{array}$ & $\begin{array}{r}187 \\
87 \\
46\end{array}$ & $\begin{array}{r}33.04 \\
15.37 \\
8.13\end{array}$ & $\begin{array}{l}51 \\
15 \\
13\end{array}$ & $\begin{array}{r}38.93 \\
11.45 \\
9.93\end{array}$ & $\begin{array}{r}89 \\
9 \\
6\end{array}$ & $\begin{array}{r}57.79 \\
5.84 \\
3.90\end{array}$ \\
\hline Total diaphragm & 320 & 56.54 & 79 & 60.31 & 104 & 67.53 \\
\hline Total & 566 & 100.00 & 131 & 100.00 & 154 & 100.00 \\
\hline
\end{tabular}

The results are summarized in Table 7. A total of $91.22 \%$ of the sheep were positive in the titre range of 10 to 10240 and only $8.78 \%$ were negative. The frequency of the individual antibody titres is shown in Fig. 5 and is related to the three categories of sheep (ewes, rams and lambs) in Table 7. It can be summarized that the IFR technique detected specific antibodies most frequently in the titre range of 40 to 640 (in $51.28 \%$ of the animals examined). High antibody titres were found in $30.47 \%$ of the animals.

Comparison of the results of direct sarcocyst demonstration with those obtained by means of IFR is presented in Table 8 . Statistical evaluation showed a highly significant $(P<0.005)$ increase in the coincidence of the results of direct and indirect examination with increasing age of the animals. The relation between direct demonstration of the cysts and specific antibody titres is shown in Table 9. IFR detected no serological response to the presence of cysts in 43 cases, diagnosed the cysts in low (10 to 20) antibody titres in 48 sheep and in titres of 40 and higher in $85.10 \%$ of the animals, $i$. e. several times more frequently. This relation was highly significant $(P<0.005)$. The differences between the three categories of sheep were not significant.

\section{Discussion}

Sheep are intermediate hosts of four species of the genus Sarcocystis. The definitive hosts are canines and felids. Because of close contacts between these animal species Sarcocystis in spread practically in all sheep-raising countries. However, the reported extent of its incidence varies in dependence upon geographical conditions and, to a considerable degree, upon the diagnostic methods. Up to now, sarcocystosis has been diagnosed most frequently on the basis of direct methods. In the bulk of our samples we used the muscle digestion method 
Number of sheep

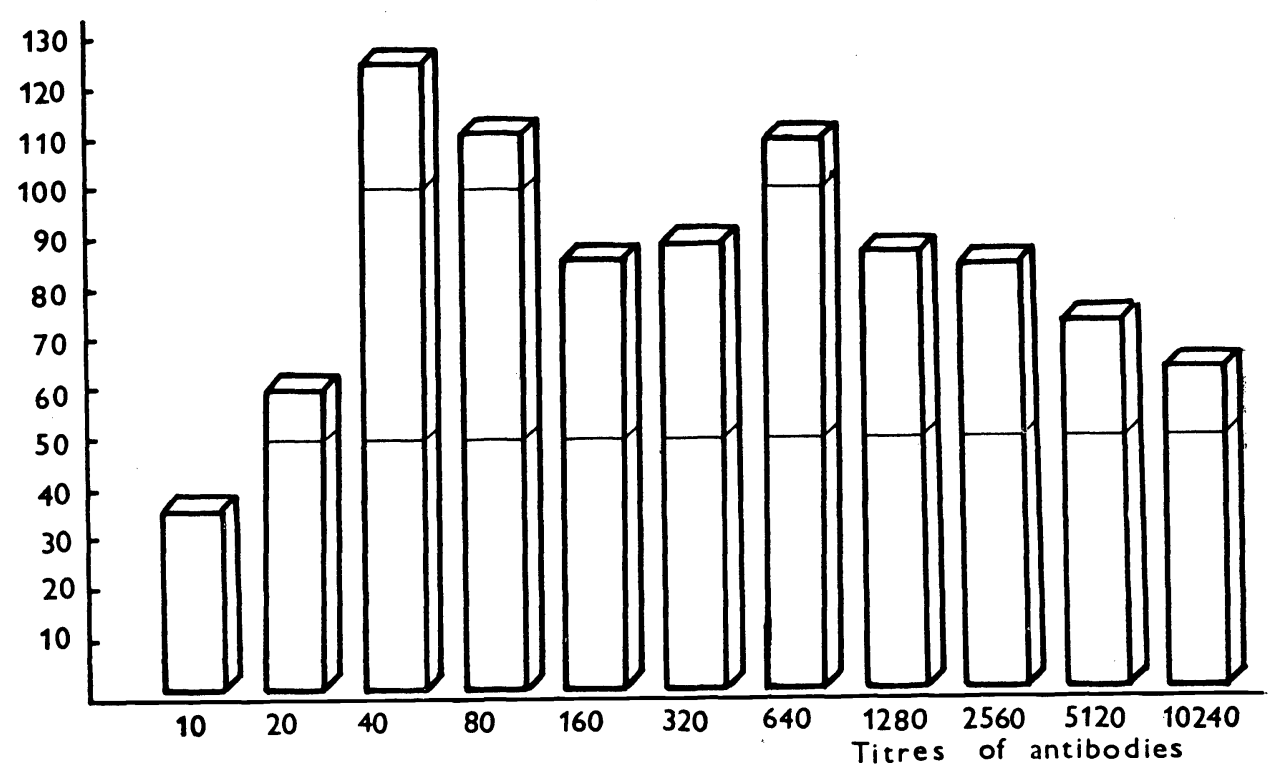

Fig. 5. Indirect immunofluorescence reaction - sarcocystis antibody titres.

which proved to be a most efficient diagnostic tool in agreement with the results. reported by Nevole and Lukešová (1981). Muscle cysts were found in $60.26 \%$ of the sheep examined.

There were considerable differences between the findings obtained in lambs and adult sheep: sarcocysts were diagnosed most fequently in ewes (in $75.10 \%$ of them) and less frequently in rams and lambs where they were found in $64.67 \%$ and $35.67 \%$ of the animals, respectively. The incidence of muscle cysts showed a highly significant $(P<0.005)$ increase with increasing age and is in keeping with the conclusions reported by Herbert and Smith (1987). Generally, lambs become infected only after they are placed on roughage which is often contaminated with Sarcocystis sp. sporocysts. The first cysts can be observed 3 months after infection at the earliest (Leek et al. 1977; O'Toole et al. 1986).

Comparison of the proportions of sheep with cysts in the oesophagus and in the diaphragm and of the respective intensities of infection showed that more cysts were detected in the diaphragm muscle. The incidence of microcysts was significantly $(P<0.05)$ higher in the diaphragm in all three categories of sheep. Having made no species differentiation of the microcysts, we can only presume that typical microcysts, and possibly also macrocysts in their initial stages of development, were present concurrently in the oesophagus and in the diaphragm. The more frequent incidence of the cysts in the diaphragm was particularly conspicuous in lambs where cysts in the oesophagus were found in only 5.26\% and those in the diaphragm in $21 \%$ of the animals. A possible explanation is that sarcocyst species producing microcysts occur more frequently in the diaphragm (Heydorn et al. 1975). Those characterized by macrocyst production, on the other hand, are located more frequently in the oesophagus (Collins et al. 1979), 
Table 7

Results of serological examination using the indirect immunofluorescence reaction (IFR)

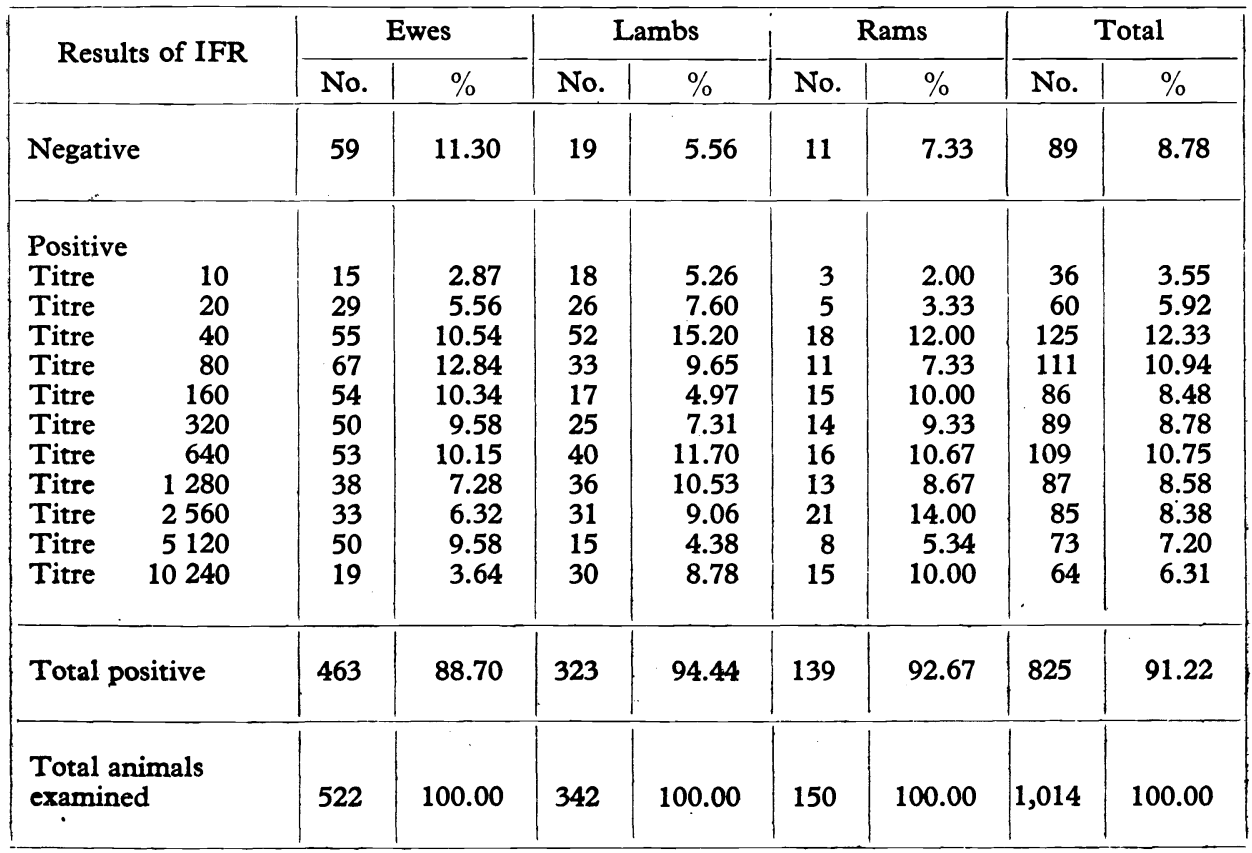

but usually are not identified in 6-to 8-month old lambs where muscle cysts are still in the process of development.

The intensity of sarcocyst infection was generally low $(+)$. In adult animals, however, the findings of moderate $(++)$ and heavy infection $(+++)$ were more frequent because the intensity of infection increased significantly $(P<0.005)$ with age. Heavy sarcocyst infection in the oesophagus muscle was recorded in $6.71 \%$ of the ewes and $4.58 \%$ of the rams but in as few as $0.65 \%$ of the lambs. Heavy infection in the diaphragm muscle was found in $8.13 \%$ of the ewes, $9.93 \%$ of the rams and $3.90 \%$ of the lambs. The results of direct examination can be summarized to the effect that most muscle cysts were produced by species having dogs as their definitive hosts, which is in keeping with the observation that more Sarcocystis sp. sporocysts were found in the faeces of dogs (Svobodová et al. 1984) than in the faeces of cats (Svobodová et al. 1983).

In our conditions macrocysts are produced by $S$.gigantea. Another species known to produce macrocysts is $S$. medusiformis. The latter was not demonstrated in our study and its incidence is probably limited to Australia and New Zealand (Levine 1985). In both cases the definitive host is the cat. In our study macrocysts were found in $3.27 \%$ of adult sheep: in $3.45 \%$ of the ewes and in $2.67 \%$ of the rams. No macrocysts were demonstrated in the lambs. In all cases macrocysts were found in the oesophageal muscle either alone (in $0.49 \%$ ) or along with microcysts (in $3.11 \%$ of the animals). Only in one instance macrocysts were diagnosed concurrently in the oesophagus and in the diaphragm. The ratio of macrocysts to microcysts in our study was slightly different than that reported by other 
Table 8

Comparison of the results of direct demonstration of sarcocysts and indirect immunofluorescence reaction (IFR)

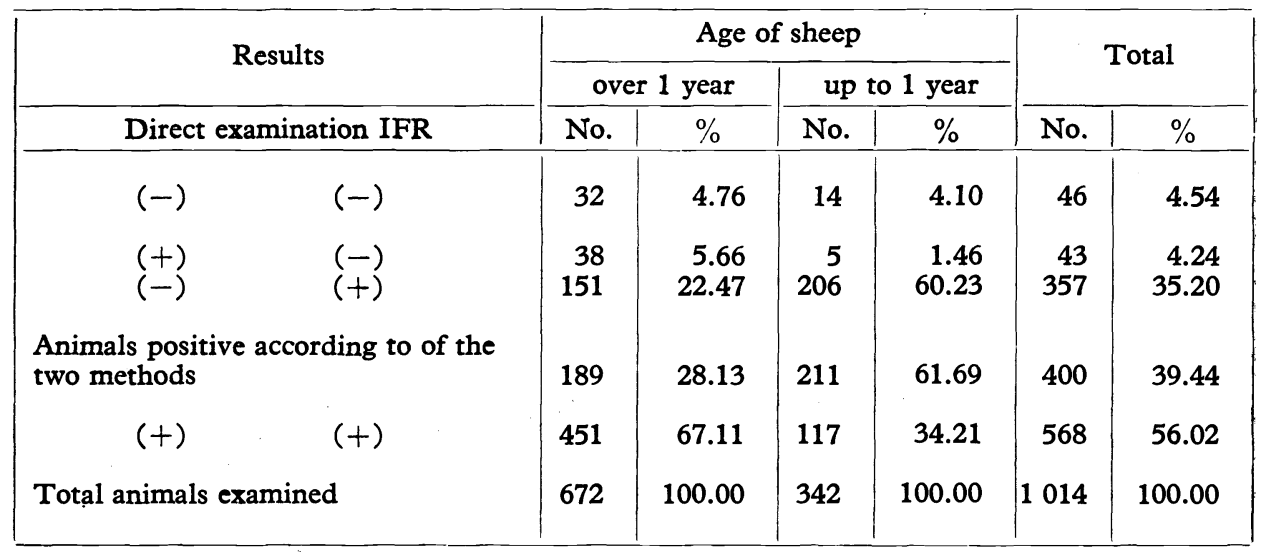

investigators; it was $1: 28$ as against $1: 20$ reported by Donát (1986). In the Slovak Republic the incidence of macrocysts is much higher than in the Czech Republic. According to Andraško (1982) it amounted to $35 \%$ and macrocysts were located not only in the oesophagus but also frequently in the diaphragm, intercostal muscle and other muscles. These findings cause considerable problems at meat inspection in the abattoir. The higher incidence of macrocysts in sheep in Slovakia is probably associated with the fact that more sheep are kept there under conditions of close contact with possible definitive hosts. In Scotland macrocysts were found in as many as $100 \%$ of the sheep examined (Britt and Baker 1983). In other countries their incidence was reported to range between $6.7 \%$ and $18.2 \%$ (Afshar et al. 1974; Bratberg et al. 1982; O'Donoghue and Ford 1986).

From our results of direct examination we concluded that the probability of detecting muscle cysts is increased by examining both the oesophagus and the diaphragm. Since microscopic methods incur more time and effort, a simplified diagnosis in adult sheep at the abattoir seems feasible: we recommend to examine the entire oesophagus together with the diaphragm by visual inspection and then examine the diaphragm muscle with a microscopic method. In lambs, however, visual inspection is by no means a satisfactory diagnostic tool and microscopic examination is a necessity; the most suited organ for this examination is the diaphragm.

For serological examination of the samples we used the IFR. This method revealed more positive animals than the direct demonstration of sarcocysts. Antibodies were detected in $91.22 \%$ of the sheep, a finding at the upper limit of the data reported by other investigators (Boch et al. 1978; Arnaudov and Belchev 1987 , a. o.). In our study even low specific antibody titres (10 to 20) were taken into account. It became apparent that muscle cysts were present even in animals with low antibody levels or in those showing no antibody response. The same conclusions were reported by Černá (1985). However, from the titre of 40 onwards the correlation between the direct demonstration of cysts and the specific antibody titres was highly significant $(P<0.005)$. In keeping with the observations re- 
Table 9

Relation between the direct demonstration of sarcocysts and the antibody titres (IFR)

\begin{tabular}{|c|c|c|c|c|c|c|c|c|c|}
\hline \multirow{3}{*}{\multicolumn{2}{|c|}{ Results of IFR }} & \multicolumn{8}{|c|}{ Direct demonstration of sarcocysts in muscles } \\
\hline & & \multicolumn{2}{|c|}{ Ewes } & \multicolumn{2}{|c|}{ Rams } & \multicolumn{2}{|c|}{ Lambs } & \multicolumn{2}{|c|}{ Total } \\
\hline & & No. & $\%$ & No. & $\%$ & No. & $\%$ & No. & $\%$ \\
\hline Neg & & 35 & 8.92 & 3 & 3.09 & 5 & 4.10 & 43 & 7.04 \\
\hline \multicolumn{10}{|c|}{ Positive } \\
\hline Titr & 10 & 8 & 2.04 & 3 & 3.09 & 5 & 4.10 & 16 & 2.62 \\
\hline Titr & 20 & 24 & 6.12 & 2 & 2.06 & 6 & 4.92 & 32 & 5.24 \\
\hline Titr & 40 & 48 & 12.24 & 9 & 9.28 & 21 & 17.21 & 78 & 12.77 \\
\hline Titr & 80 & 57 & 14.54 & 7 & 7.22 & 10 & 8.20 & 74 & 12.11 \\
\hline Titr & 160 & 38 & 9.69 & 9 & 9.28 & 9 & 7.38 & 56 & 9.17 \\
\hline Titr & 320 & 38 & 9.69 & 11 & 11.34 & 13 & 10.65 & 62 & 10.15 \\
\hline Titr & 640 & 46 & 11.73 & 10 & 10.31 & 17 & 13.93 & 73 & 11.95 \\
\hline Titr & 1280 & 30 & 7.65 & 9 & 9.29 & 16 & 13.11 & 55 & 9.00 \\
\hline Titr & 2560 & 23 & 5.87 & 19 & 19.59 & 7 & 5.74 & 49 & 8.00 \\
\hline Titr & 5120 & 33 & 8.42 & 6 & 6.18 & 5 & 4.10 & 44 & 7.20 \\
\hline Titr & 10240 & 12 & 3.06 & 9 & 9.28 & 8 & 6.56 & 29 & 4.75 \\
\hline \multicolumn{2}{|c|}{ Total } & 392 & 100.00 & 97 & 100.00 & 122 & 100.00 & 11 & 100.00 \\
\hline
\end{tabular}

ported by Reiter et al. (1981) it can therefore be recommended that screening tests of exploratory character should start at the titre of 40 . The largest proportion of the cysts was detected at the titres of 40 to 640 . High antibody titres provide evidence of acute infection. They were found mainly among lambs and were accompanied by the incidence of cysts in a lower percentage of animals.

In ewes muscle cysts were found in $75.10 \%$ and specific antibodies in $88.70 \%$ of the animals. In rams the proportion of those showing muscle cysts was $64.67 \%$ and that of serologically positive animals was $92.67 \%$. The greatest difference between the direct demonstration of sarcocysts and the presence of antibodies was found in lambs: direct examination detected $35.67 \%$ positive animals, whereas serological examination using the IFR revealed $94.44 \%$ lambs with specific antibodies. These differences were most likely due to the fact that in the initial stages of infection antibody response occurs before detectable muscle cysts have devoloped. This is characteristic particularly of lambs where the proportion of animals showing cysts is relatively low owing to their age but antibody response is considerable and indicates primary infection.

In the present study the results of direct and indirect examination were compared and statistically analysed in an attempt to find a suitable method for the diagnosis of sarcocystosis. In adult sheep the results of the two methods coincided $71.87 \%$ of the animals, whereas in lambs a discrepancy was found $61.69 \%$ of the animals examined. The coincidence of the results of the two methods showed a highly significant $(P<0.005)$ increase with age. In the light of these observations it is concluded that at meat inspection of adult sheep carcasses direct examination of muscle cysts is sufficient, whereas in lambs it must be combined with serological methods. 
Využití trávicí metody a nepř́imé imunofluorescenční reakce $\mathbf{k}$ diagnostice sarkocystózy ovcí

V období od řína 1985 do června 1988 jsme prováděli přímé a nepřímé vyšetření ovcí zaměřené na výskyt a diagnostiku sarkocystózy. Celkem bylo vyšetřeno 1014 ovcí. V tomto počtu je zahrnuto 522 bahnic, 150 beranů a 342 jehňat. Zvírata pocházela ze spádových oblastí jatek v Tišnově, Klatovech, Strakonicích a Nymburku.

Př́mým vyšetřením trávicí metodou byly svalové cysty zjištěny u 75,10 \% bahnic, $64,67 \%$ beranů a $35,67 \%$ jehňat. Makro a mikrocysty se vyskytly u zvírat $\mathrm{v}$ poměru $22: 608$. Makrocysty jsme nacházeli pouze u dospělých jedinců $(3,27 \%$ bahnic a beranů) ve svalovině jícnu a v jednom případě i bránici. Mikrocysty byly lokalizovány nejčastěji $\mathrm{v}$ bránici a jejich intenzita se statisticky významně zvyšovala s věkem zviŕat $(P<0,005)$.

Serologickým vyšetřením krve nepřimou imunofluorescenční reakcí (NFR) jsme detekovali specifické protilátky u 88,70\% bahnic, $91,22 \%$ beranů a $94,44 \%$ jehňat. Koincidence přimého průkazu svalových cyst a serologického vyšetření krve byla u dospělých zvírat $\mathrm{v} 71,87 \%$, zatímco u jehňat jsme zaznamenali vysokou dyamickou diskrepanci $(61,69 \%)$. Statisticky vysoce významná korelace byla zaznamenána mezi pryímým průkazem svalových cyst a hladinou specifických protilátek zjištovaných NFR v titru 40 a vyšším.

\section{Использование пищеварительного метода и косвенной иммүнофлуоресцентной реакции в диагностике саркоцистоза овец}

С октября 1985 г. по июнь 1988 г. проводили прямое и косвенное исследование овец, направленное на выявление и диагностику саркоцистоза. В итоге обследовали 1014 овец. В данное число входят 522 сүягных овец, 150 баранов и 342 ягненка. Происхождение животных из центров Тишнов, Клатови, Страконице и Нимбург.

Прямым исследованием пищеварительным методом мышечные кисты были выявлены у 75,10 \% суягных овец, $64,67 \%$ баранов и $35,67 \%$ ягнят. Макро и микрокисты встречались у животных в соотношении 22 : 608. Макрокисты находили только у взрослых особей $(3,27 \%$ сүягных овец и баранов) в мышечной ткани зева и в одном случае также в деафрагме. Микрокисты чаще всехо встречались в диафрагме и их интенсивность статистически значимо увеличивалась с возрастом животного $(P<0,005)$.

Серологическим исследованием крови косвенной иммунофлуоресцентной реакцией (NFR) были выявлены специфические антитела у $88,70 \%$ сүягных овец, $91,22 \%$ баранов и $94,44 \%$ ягнят. Совпадение прямого определения мышечных кист и серологического исследования крови наблюдалось у взрослых особей в $71,87 \%$, между тем как у ягнят отметили высокое динамическое расхождение $(61,69 \%)$. Статистически весьма значимая корреляция наблюдалась между прямым определением мышечных кист и уровнем специфических антите, выявляемых косвенной иммунофлуоресцентной реакцией в титре 40 и больше. 


\section{Acknowledgements}

Thanks are also due to Mrs $M$. Vaňatková for technical assistane and to Mr. J. Kudrna of the Department of Electron Microscopy of the Veterinary Research Institute, Brno, for the photodocumentation.

\section{References}

ADAMCZYK, E.-CHMIELOWSKI, W.: Sarkocystóza jatečných zviřat. Veterinářství, 37, 1987: 305-307.

AFSHAR, A.-NAGHSNINEN, R.-NESHAT, H.: Incidence of sarcosporidiosis in sheep in Iran. Tropical Animal Health and Production, 6, 1974: 192.

ANDRASKKO, H.: Výskyt sarkocystózy u oviec. Ćs. spol. parazitologická, Praha-Košice, 22, 1982: 7.

ARNAUDOV, D.-BELCHEV, L.: Sarcocystis infection in sheep. 5. národní konference parazitologická, Varna 1. - 3. 10. 1987.

BERFLER, K. G.-ERBER, M.-BOCH, J.: Untersuchungen zur Ưberlebensfähigkeit von Sporozysten bzw. Oozysten von Sarcocystis, Toxoplasma, Hammondia und Eimeria unter Labor- und Freiland Bedingungen. Berl. u. Münch. tierärztl. Wschr., 93, 1980: 288-293.

BOCH, J.-LAUPNEIMER, K. E.-ERBER, M.: Drei Sarkosporidienarten bei Schlachtrindern in Süddeutschland. Berl. u. Münch. tierärztl. Wschr., 91, 1978: 426-431.

BRATBERG, B.-HELLE, O.-HILALI, M.: Sarcocystis infection in sheep from south-western Norway. Acta Vet. Scand. 23, 1982: 221-234.

BRITT, D. P. - BAKER, J. R.: Cysts of Sarcocystis tenella in North Ronalsay sheep. Vet. record, 113, 1983: 516.

COLIINS, G. H.-ATKISON, E.-CHARLESTON, W. A. G.: Studies on Sarcocystis species III. The macrocysts species of sheep. N. Z. vet. J., 27, 1979: 204-206.

ČERNÁ, Ž.: Aktuální otázky výzkumu sarkosporidií užitkových zvírat. Referát na symposiu „40 let rozvoje československé parazitologie“, Ceské Budějovice 26. -28. 6. 1985.

ČERNÁ, Ž.-MERHAUTOVÁ, V.: Sarcocystis in cattle and sheep at Prague abattoir. Folia parasitol. (Praha), 28, 1981: 125-129.

DIÉZ-BAŇOS, P.: Sobre la prevalencia de la Sarcosporidiosis ovina on la provincia de Leon, con un estudie comparative de dixersos metode diagnosticos. An. Fac. Vet. Leon, 24, 1978: $195-199$.

DONÁT, K.: Studie o rozšiření a biologii sarkosporidií domácích zviřat. Závěrečná zpráva VI-1-8/3, Parazitologický ústav CSAV, Ceské Budějovice 1986, 54 p.

DUBEY, J. P.: Toxoplasma, Hammondia, Besnoitia, Sarcocystis, and Other Tissue Cyst-forming Coccidia of Man and Animals. In: Parasitic Protozoa (Kreier, J. P., editor), Academic Press Inc., New York 1977, vol. 3, pp. 101-237.

DUBEY, J. P.-LEEK, R. G.-FAYER, R.: Prevalence, transmission, and pathogenicity of S. gigantea of sheep. J. A. V. M. A., 188, 1986.

GUT, J.: Effectiveness of methods used for the detection of Sarcosporidiosis in farm animals. Folia Parasitol. (Praha), 29, 1982: 289-295.

HERBERT, J. V. - SMITH, T. S.: Sarcocystis. Parasitol. Today, 3, 1987: 16-21.

HEYDORN, A. O.-GESTRICH, V. R.-MEHLHORN, H.-ROMMEL, M.: Proposal for a new nomenclature of the Sarcosporidiosis. Z. Parasitenkde, 48, 1975: 73-82.

LEEK, R. G. -FAYER, R.-JOHNSON, A. J.: Sheep experimentally infected with Sarcocystis from dogs. I. Disease in young lambs. J. Parasitol., 63, 1977: 642-650.

LEVINE, N. D.: Veterinary Protozoology, State University Press, Iowa, Ames 1985, 414 p.

NEVOLE, M. - LUKEŚOVÁ, D.: Metody př́mé detekce sarkocyst a jejich diagnostická spolehlivost. Veter. Med. (Praha), 26, 1981: $581-584$.

NEVOLE, M. - LUKEŚOVÁ, D. - SVOBODOVÁ, V.: Studium sarkocystózy skotu a ovcí. Závěrečná zpráva VÚ S-11-529-104/04-11, Brno 1984, $21 \mathrm{p}$.

O'DONOGHUE, P. J.-FORD, G. E.: The prevalence and intensity of Sarcocystis sp. infection in sheep. Austral. veter. J., 63, 1986: 273-278.

O'TOOLE, D.-DUFFELL, S. J.-UPCOTT, D. N.-FREVIN, D.: Experimental microcyst sarcocystis infection in lambs: Pathology, Veterinary Record, 119, 1986: 525-531.

POMROY, W. E.-CHARLESTON, W. A. G.: Prevalence of dog-derived Sarcocystis sp. in some New Zealand lambs. N. Z. vet. J., 35, 1987: 141-142.

REISENAUER, R.: Metody matematické statistiky a její aplikace. 2nd ed., Práce, Praha 1970, $239 \mathrm{p}$. 
REITER, J. - WEILAND, G.-ROSCHER, B.-MEYER, J.-FRAHM, K.: Studies on the Serological Diagnosis of Experimentally Induced Bovine and Ovine Sarcocystosis. Berl. u. Münch. tierärztl. Wschr., 94, 1981: 425-430.

SVOBODOVÁ, V.: Sarkocystóza ovcí. PhD. Thesis University of Veterinary Science, Brno 1988, $123 \mathrm{p}$.

SVOBODOVÁ, V.-NEVOLE, M.: Sarkocystóza jatečných ovcí. Veter. Med. (Praha), 30, 1985: $675-679$.

SVOBODOVÁ, V.-NEVOLE, M.-ŠIMEČKOVÁ, A.: Kokcidie u koček v brněnské oblasti. Veterinářství, 35, 1983: 517-519.

SVOBODOVÁ, V.-SVOBODA, M.-NEVOLE, M.: Výskyt kokcidií u psủ z Brna a okolí. Veter. Med. (Praha), 29, 1984: 627-632. 